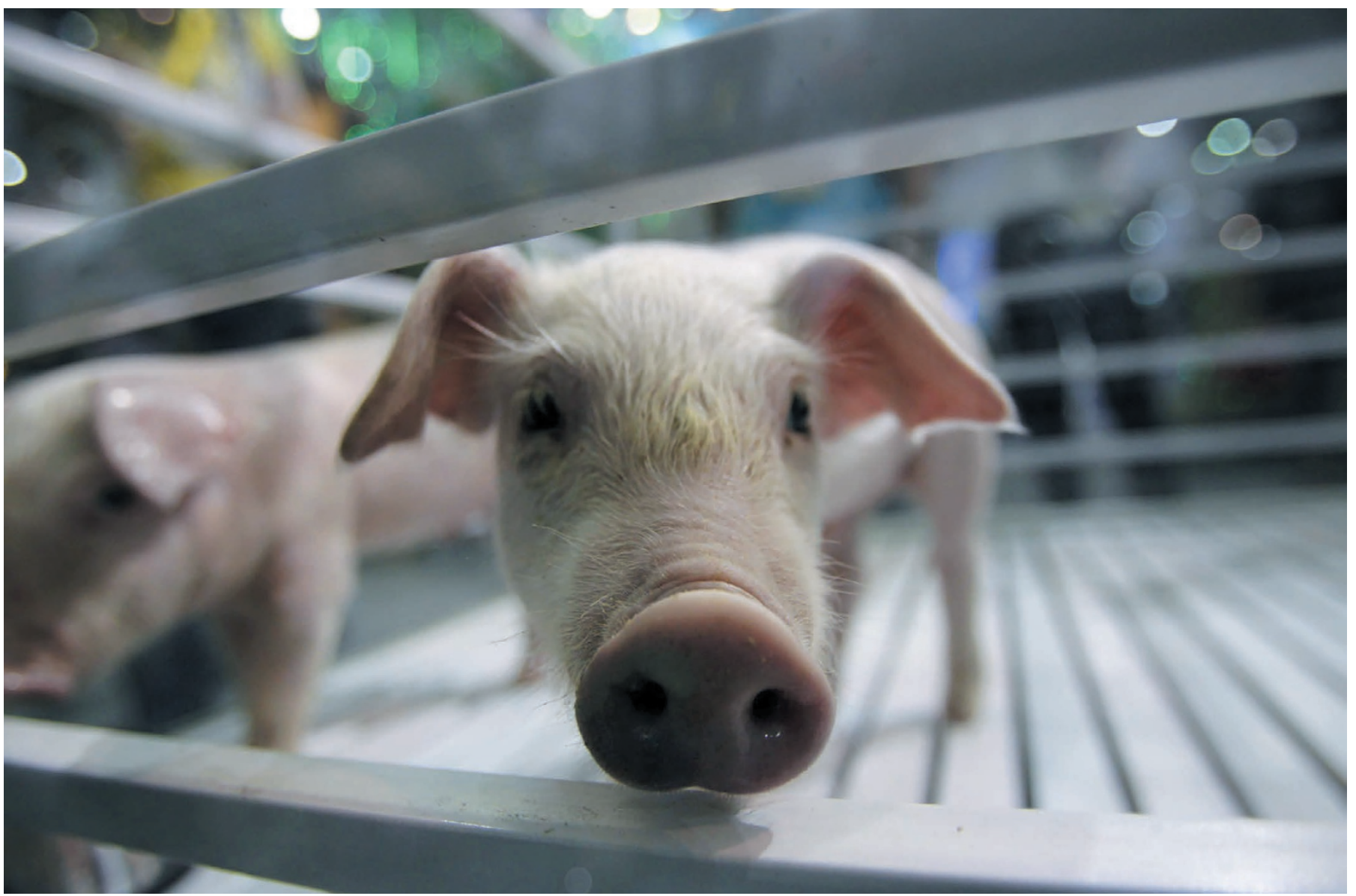

\title{
Running with scissors
}

\section{John Harris probes a study on the science and ethics of genome editing.}

$\mathrm{I}$ n Redesigning Life, molecular pharmacologist John Parrington has produced a veritable compendium of games that scientists like him can play with life itself. He invites us to imagine the potential of life forms "whose very genetic recipe was manufactured in a chemistry lab using new components never seen before on Earth". What larks!

What follows is a thorough and comprehensive account of the methodologies for altering life that have been or are being developed, and the directions that they may take in future. Those methodologies include the insertion or deletion of genes, the engineering of synthetic genes and the design of creatures unprecedented in nature. As Parrington shows, many of the technologies are familiar: for example, designing immunity to disease through vaccination, or animal and plant breeding. He ends with the concept of a "redesigned planet", replete with new types of people, as well as designer babies, pets, plants

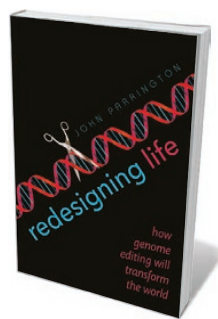

Redesigning Life: How Genome Editing Will

Transform the World

JOHN PARRINGTON

Oxford University

Press: 2016.

\section{of the nature of this problem.}

and drugs. Invoking the catchphrase of comic-book superhero Spiderman, "with great power comes great responsibility", he touches on the challenges that such a possibility would entail.

However, Parrington's way of dealing with the ethical issues raised by the technologies that he so gleefully explores is rather limited. Three examples give a sense

Early on, he notes that in agriculture, it is important to ensure that genome editing benefits the majority of humanity rather than stuffing the coffers of vast corporations. But he fails to say how this might be achieved. Given that we cannot ensure this for any product or service in any field, I wonder what this criticism amounts to? Attempting global distributive justice is a major political problem of moral significance, but really, only governments can approach such utopian ideals. Demanding the impossible can never be rational ethics.

Later, Parrington worries about designer babies engineered for looks, intelligence or extraordinary talent (opining, "Such fears run deep among scientists"). But he offers not a word about the cogency of the fears, or about the moral basis - or lack of it - for how people see things. Parrington also questions the use of stem-cell technology in helping older women to have children: "Would this be seen as liberating or an irresponsible extension

\section{$\rightarrow$ NATURE.COM}

For more on science in culture see:

nature.com/

booksandarts 
of a woman's reproductive age?" However, how it would be seen is a sociological question. The ethical responsibility involves showing how it should be seen, and why.

If Parrington is serious about the need to address ethical issues when tinkering with genes, more explanation is needed of just what the ethical issues are and how they might be resolved. Such an attempt involves, at the very minimum, an analysis of the types of design involved in, for example, producing designer babies; it also involves giving

"Why might it be better to increase intelligence by education, diet or exercise than through gene editing?" reasons to morally prefer some sorts of design or ways of designing to others, as I explain in my book How to be Good (Oxford University Press, 2016). Why might it be better to aim to increase cognitive powers and perhaps even intelligence by education, diet or exercise than through gene editing or drugs? One would also need to identify elements that would clearly be unethical to design into a person, such as an increased propensity to disease or premature death.

Most importantly, one would need to consider why attempts at design are morally worse (if they are) than simply leaving things to the genetic lottery of sexual reproduction. There is a story that in the early twentieth century, the pioneering modern dancer Isadora Duncan suggested to writer George Bernard Shaw that they should have a child, surmising that with her looks and his brains any progeny would have huge advantages. The ever-rational Shaw responded, "But what if it had your brains and my looks?" Was Duncan's proposal unethical or just misconceived? What would or should have made such a proposal ethically problematic? And if it was not ethically problematic, why might more 'techie' attempts become unethical?

Gene editing is now the stuff of do-ityourself 'garage research', opening up nightmares for regulation and oversight. Our best hope is to clarify what it is morally permissible to do behind closed doors. I have no quarrel with the idea of redesigning our planet, or indeed ourselves, if the elements of design promote life, liberty and the pursuit of happiness for those creatures to whom such things matter. These objectives are not only ethical, but mandatory if intelligent life forms are to survive into the far future. The best way of ensuring that this is allowed to happen is to be clear about which are and which are not morally permissible means to this clearly desired and desirable end.

John Harris is professor emeritus in the ethics of science and technology at the University of Manchester, UK. e-mail:john.harris@manchester.ac.uk

\section{Books in brief}

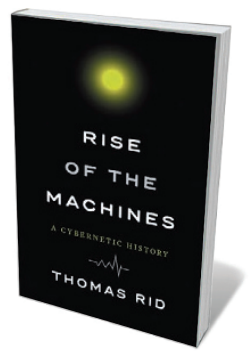

Rise of the Machines: A Cybernetic History

Thomas Rid W. W. NORTON (2016)

Cybernetics, the science of communication and control in machines and organisms, has had a tangled history. Here, professor of war studies Thomas Rid unravels seven strands of it, starting with mathematician Norbert Wiener's book Cybernetics (1948). Wiener's big idea first gained traction in post-war research on ballistic calculations in airborne warfare. It then popped up in 1950s dreams of automated utopias, the concept of benevolent machines serving humanity in the 1970s and, from the 1980s, applications such as virtual reality, public-key cryptography and, ominously, cyberwar.

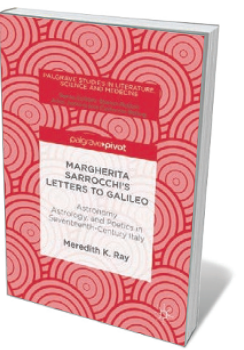

Margherita Sarrocchi's Letters to Galileo

Meredith K. Ray PALGRAVE (2016)

When astronomer Galileo Galilei was a rising star, he corresponded with the formidable Margherita Sarrocchi — a salon host, epic poet and polymath versed in geometry, natural philosophy and logic (J. Rampling Nature 520, 154-155; 2015). In this rich analysis of the exchange, Meredith Ray shows how the pair found common ground in assessing each other's work, whether the discovery of Jupiter's satellites or the crafting of poetic nuance. An illuminating explication of the dynamics in early-modern arts and sciences, complemented by the first full English translation of the letters.

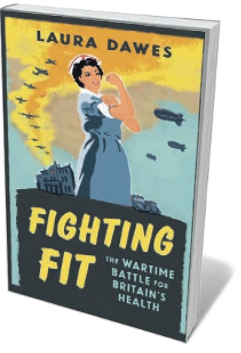

Fighting Fit: The Wartime Battle for Britain's Health Laura Dawes WEIDENFELD \& NICOLSON (2016)

Historian Laura Dawes digs into that other victory of the Second World War: public health in Britain. There had been dire predictions, such as epidemics incubated in air-raid shelters. But by war's end, UK rates of almost all infectious diseases had dropped, thanks to the Medical Research Council, Nobel laureates such as physiologist Andrew Huxley, hordes of researchers and a willing public. Dawes' sparky account demonstrates how that rare teamwork advanced emergency care, preventive medicine, the treatment of insect-borne disease and, ultimately, the formation of the National Health Service.

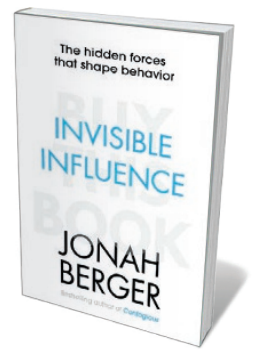

Invisible Influence: The Hidden Forces that Shape Behavior Jonah Berger SIMON \& SCHUSTER (2016)

In his best-seller Contagious (Simon \& Schuster, 2013), marketing scholar Jonah Berger explored influence through word of mouth a territory much probed by social psychologist Robert Cialdini (T. Dietz Nature 479, 176; 2011). Here, Berger turns the tables, examining the hidden social influences that nudge us into choosing everything from jobs to desserts. Neatly compressing findings in ethology, economics and more, he looks at imitation, differentiation, motivation and the see-saw between novelty and familiarity. Crowded with insights - not least, for wary voters.

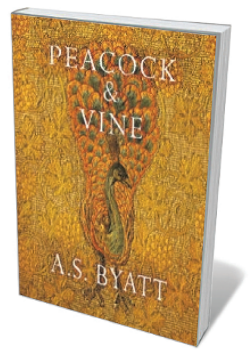

Peacock and Vine: Fortuny and Morris in Life and at Work A. S. Byatt CHATTO \& WINDUS (2016) In this faceted gem of a book, novelist A. S. Byatt muses on design revolutionaries Mariano Fortuny and William Morris. Fortuny, galvanized by ancient Minoan fabrics, printed scarves with patterns of murex shells and trilobite fossils, and devised intricate, permanent pleating for his sinuous 'Delphos' gowns. Morris recorded the "geometry of branches and petals and fruits", bringing hedgerow and copse indoors with motifs and natural dyes that transformed typography, wallpaper and textiles. An ingenious comparison. Barbara Kiser 